Ekspansi: Jurnal Ekonomi, Keuangan, Perbankan dan Akuntansi

ISSN (Online): 2580-7668 ISSN (Print): 2085-5230

Vol. 11, No. 2 (November 2019), Hal. 141 - 156

\title{
EFEKTIVITAS PENERAPAN PENGENDALIAN INTERNPADA USAHA MIKRO, KECIL DAN MENENGAH (UMKM) DI KOTA BANDUNG
}

\author{
Kamalah Saadah ${ }^{1}$ \\ ${ }^{1}$ Jurusan Akuntansi, Politeknik Negeri Bandung, Bandung, Indonesia \\ Email Korespondensi: kamalah.mala@gmail.com
}

\begin{abstract}
Competition during the ASEAN Economic Community (MEA) encourages all business units to be able to optimize their performance. Actors of MSMEs (Micro, Small and Medium Enterprises) which have a large contribution to the nation's economy need to look at internal controls on their entities so they can have competitiveness. This study aims to determine the internal control applied by MSMEs in the city of Bandung. This has become important to observe given the different characteristics of MSMEs with large companies, especially in terms of the number of workers and the division of tasks. A series of questionnaires in the form of a number of questions regarding internal control for small entities will be filled by MSME respondents to find out the description of internal control practices in MSMEs. The method used in this study is a quantitative method with a descriptive approach which in this study will be described regarding internal control of MSMEs in the city of Bandung. The results of the study show that in general the effectiveness of internal controls implemented by MSMEs in Bandung is considered quite good. This allows researchers to propose recommendations as a consideration for planning internal control strategies for MSME activists in general.
\end{abstract}

Keywords: Effectiveness, Internal Control, MSMEs

Abstrak: Persaingan pada masa Masyarakat Ekonomi ASEAN (MEA) mendorong seluruh unit bisnis untuk dapat mengoptimalkan kinerjanya. Pelaku UMKM (Usaha Mikro Kecil dan Menengah) yang mana memiliki kontribusi besar bagi perekonomian bangsa perlu mencermati pengendalian intern pada entitasnya sehingga dapat memiliki daya saing. Tujuan dilaksanakannya penelitian ini adalah untuk mengetahui penerapan pengendalian intern yang dilakukan oleh UMKM di Kota Bandung. Hal ini menjadi penting untuk dicermati mengingat berbedanya karakteristik UMKM dengan perusahaan besar terutama dari segi jumlah pekerja dan pembagian tugasnya. Serangkaian kuisioner berupa sejumlah pertanyaan mengenai pengendalian intern untuk entitas kecil akan diisi oleh UMKM responden untuk mengetahui gambaran praktik pengendalian intern pada UMKM. Metode yang digunakan dalam penelitian ini adalah metode kuantitatif dengan pendekatan deskriptif yang mana dalam penelitian ini akan dideskripsikan mengenai pengendalian intern pada UMKM di Kota Bandung. Hasil penelitian menunjukan bahwa secara umum efektivitas pengendalian intern yang diterapkan para pengiat UMKM di Kota Bandung dinilai cukup baik. Hal ini memungkinkan peneliti untuk mengajukan rekomendasi sebagai pertimbangan untuk perencanaan strategi pengendalian intern kepada para penggiat UMKM secara umum.

Kata Kunci: Efektivitas, Pengendalian Intern,UMKM

DOI: $10.35313 /$ ekspansi.v11i2.1338

Riwayat Artikel:

Diterima: $13-07-2019$

Direvisi: $14-11-2019$

Disetujui: $17-11-2019$ 


\section{PENDAHULUAN}

Era perdagangan bebas Masyarakat Ekonomi ASEAN (MEA) menuntut setiap masyarakat Indonesia untuk selalu kreatif dalam menggali potensi pendapatan. Salah satu hal yang menjadi sorotan yaitu sektor Usaha Mikro, Kecil dan Menengah (UMKM). Sektor UMKM dapat mengurangi pengangguran sehingga mendorong perekonomian Indonesia, hal ini terbukti saat krisis ekonomi 1998, hanya sektor UKM yang bertahan dari collapse-nya perekonomian (kemenkeu.go.id: 2015). UMKM dianggap memiliki peran penting dalam pengentasan kemiskinan di Indonesia. Kontribusi sektor Usaha Mikro, Kecil dan Menengah (UMKM) terhadap produk domestik bruto (PDB) semakin menggeliat dalam lima tahun terakhir, begitu pula halnya dengan penyerapan tenaga kerjanya. Kementerian Koperasi dan Usaha Kecil Menengah (UKM) mencatat kontribusi sektor UMKM meningkat dari 57,84 persen menjadi 60,34 persen (cnnindonesia.com: 2016). Jumlah UMKM di Indonesia semakin banyak yakni mencaapai 99,99\% dari total pelaku usaha nasional dan UMKM memberikan kontribusi terhadap kesempatan kerja sebanyak 96,99\% (beritasatu.com: 2015).

Masyarakat Ekonomi ASEAN (MEA) memiliki dua konsekuensi yang berlawanan, satu sisi MEA akan meningkatkan pasar bagi masyarakat Indonesia yang produktif dan kreatif, namun di sisi lain MEA hanya akan menjadi pasar bagi produk negara-negara di ASEAN. Menghadapi tantangan yang sangat besar tersebut, pemerintah telah dan terus berupaya keras untuk memajukan sektor UMKM dengan berbagai kebijakan dan program agar peranannya semakin meningkat terutama dalam penyediaan lapangan kerja dan mengurangi kemiskinan. Namun tentu saja bukanlah hal yang mudah dalam meningkatkan pertumbuhan ekonomi di sektor UMKM ini. Setidaknya ada empat kendala yang dihadapi UMKM, yaitu pembiayaan, teknologi dan inovasi produk, riset pasar dan terakhir inefisiensi (kabarbisnis.com: 2014).

Kendala yang akan menjadi perhatian disini adalah kendala yang terakhir, yakni inefisiensi. Inefisiensi erat kaitannya dengan pengendalian intern perusahaan yang mencangkup berbagai aspek. Sistem pengendalian intern didefinisikan sebagai suatu sistem yang meliputi struktur organisasi, metode dan ukuran-ukuran yang dikoordinasikan untuk menjaga kekayaan organisasi, mengecek ketelitian dan keandalan data akuntansi, mendorong efisiensi dan mendorong dipatuhinya kebijakan manajemen (Mulyadi: 2016). Pengendalian dibutuhkan tidak hanya bagi perusahaan besar, namun juga perusahaan kecil. Terlebih perusahaan kecil cenderung berpotensi terjadinya kecurangan daripada perusahaan besar (Montgomery, 2003).

Perusahaan kecil di Indonesia masih cenderung mengabaikan konsep dan praktik pengendalian intern, walaupun sebetulnya model pengendalian yang dikhususkan untuk perusahaan berskala kecil sudah ada sejak lama. Model tersebut dicetuskan oleh Stelzer (1964) dalam kuisioner pengendalian intern (Internal Control Questionaire), sehingga seharusnya praktik pengendalian intern bagi UMKM bukanlah merupakan hal yang baru. Selain itu, pada tahun 1978, Jof telah membuat kuisioner yang dikhususkan untuk memonitor dan evaluasi atas pengendalian intern bagi perusahaan berskala kecil. 
Ditinjau dari segi biaya yang dikeluarkan untuk proses pengendalian intern yang tidak bisa dibilang sedikit, yaitu membutuhkan biaya untuk proses akuntansi juga tambahan sumber daya manusia, perusahaan kecil terlebih UMKM dianggap tidak perlu menerapkan sistem pengendalian intern. Dilihat dari tujuan sistem pengendalian intern yaitu menjaga harta kekayaan perusahaan, maka dapat ditarik garis besar bahwa pengendalian intern sangat diperlukan untuk seluruh perusahaan, bukan hanya perusahaan besar saja. Sehingga mencermati pengendalian pada UMKM menjadi hal yang sangat penting dalam rangka meningkatkan pertumbuhan dan ketahanan UMKM dalam menghadapi MEA.

Berbagai pihak yang terkait langsung dengan UMKM menaruh perhatian lebih, seperti Ikatan Akuntan Indonesia yang menyusun Standar Akuntansi Keuangan EMKM dan efektif per Januari 2018. Selain itu terdapat usaha-usaha untuk meningkatkan perekonomian melalui peningkatan kinerja UMKM dengan cara yang sangat inovatif, seperti yang terjadi di Kota Bandung. Dukungan dari Pemerintah Kota Bandung sangat menunjang perkembangan UMKM setempat. Salah satu program kreatif terbarunya yaitu Little Bandung yang merupakan program yang digagas Pemerintah Kota Bandung untuk membangun brand UMKM Bandung di Malaysia (Kompas.com: 2016). Dengan ditandatanginya piagam kerjasama antara Walikota Bandung M. Ridwan Kamil bersama Head Of Economic Growth Initiatives APAC Facebook Clair Deevy, maka UMKM Kota Bandung akan lebih dipandang lagi bahkan di dunia Internasional. Kota Bandung, dipilih karena memiliki industri kecil berkualitas serta mempunyai keinginan besar untuk bersaing di pasar Asia (goukm.id: 2016). Inovasi ini yang menjadikan Bandung digunakan sebagai contoh bagi kota-kota lain dalam pengembangan UMKM.

Selain inovatif, Pemerintah Kota Bandung menargetkan menciptakan 100000 lapangan kerja baru selama lima tahun pemerintahan Ridwan Kamil. Pada tahun 2016, Kota Bandung menargetkan pencapaian 35.000 wirausahawan baru yang dibebankan kepada 5 dinas, salah satunya adalah Dinas Koperasi, Usaha Kecil Menengah, Perindustrian, dan Perdagangan (KUKM dan Perindag) Kota Bandung (bandungkita.net, 2016). Dapat disimpulkan bahwa UMKM di Kota Bandung memiliki fokus dan semangat yang baik untuk terus berkembang.

Pemaparan di atas merupakan hal-hal yang melatarbelakangi penulis untuk meneliti "Efektivitas Penerapan Pengendalian Intern pada UMKM di Kota Bandung." Hal yang mendasarinya adalah pesatnya peningkatan pertumbuhan UMKM di Kota Bandung dikaitkan dengan pengendalian intern yang dilakukan

Tujuan dari penelitian ini adalah untuk mengidentifikasi bagaimana penerapan pengendalian intern yang terdapat pada UMKM di Kota Bandung dan mengungkapkan unsur-unsur pengendalian intern yang belum diterapkan secara efektif pada UMKM di Kota Bandung. Penelitian ini diharapkan dapat memberikan sumbangsih pemikiran bagi ranah akuntansi serta menjadi salah satu referensi bagi peneliti yang sama dalam hal kajian Efektivitas Penerapan Pengendalian Intern pada UMKM. Selain itu, hasil penelitian ini diharapkan dapat digunakan sebagai usulan kebijakan bagi pelaku bisnis UMKM dalam menjaga harta kekayaannya. 


\section{TINJAUAN PUSTAKA}

\subsection{Pengertian Efektivitas}

Arens et.al. (2015) mengemukakan bahwa yang dimaksud dengan efektivitas adalah "hubungan antara keluaran pusat pertanggungjawaban dengan tujuannya". Senada dengan pengertian tersebut, Arens \& Loebbecke (2006) mendefinisikan efektivitas sebagai berikut:

"Effectiveness refers to accomplishment of objective, whereas efficiency refers to resources used to achive those objective. An example of effectiveness is the production of parts without defects. Efficiency concern whether those parts are produced at minimal cost".

Jadi dapat dikatakan bahwa efektivitas mengacu kepada pencapaian tujuan yang telah ditetapkan. Efektivitas merupakan suatu pencapaian yang mana sesuai dengan rencana yang telah ditentukan.

\subsection{Definisi Pengendalian Intern}

Definisi pengendalian intern menurut publikasi dengan judul Intern Control Elements of CoManagement and The Independent Public Accountant adalah "pengawasan yang mencakup struktur organisasi dan seluruh metode dan prosedur terkoordinir yang diterapkan oleh perusahaan untuk mengamankan hartanya, mengecek ketelitian dan kepercayaan terhadap data akuntansi, mendorong kegiatan agar efisien dan mengajak untuk mentaati kebijakan perusahaan" (Harahap, 1995). Publikasi tersebut dimuat dalam laporan Committee on Auditing Procedure tahun 1949. Selajutnya dalam Statement of Auditing Procedure No. 29, yang merupakan suatu laporan komite pada tahun 1985 membagi pengendalian intern menjadi pengendalian akuntansi dan pengendalian administrasi.

Pengendalian akuntansi meliputi metode prosedur dan struktur organisasi atas perlindungan terhadap harta perusahaan, serta menjamin ketelitian dalam keuangan. Selain itu, pemisahan fungsi pencatatan dan operasional, sistem otorisasi dan pengawasan secara fisik atas kekayaan juga termasuk dalam fungsi ini. Sedangkan pengendalian administrasi meliputi metode prosedur dan struktur organisasi atas usaha untuk mengefisiensikan kegiatan operasi perusahaan dan kepatuhan atas kebijakan pimpinan. Contohnya adalah program pelatihan karyawan, pengedalian mutu, analisis statistik serta time and motion study.

\subsection{Konsep Dasar Pengendalian Intern}

Mulyadi (2013) mengemukakan beberapa konsep dasar pengendalian:

a) Merupakan suatu proses untuk mencapai tujuan tertentu. Pengendalian intern merupakan suatu rangkaian tindakan perpasif tertentu yang berfokus pada suatu tujuan.

b) Dijalankan oleh orang. Pengendalian intern bukanlah sebatas pedoman kebijakan dan formulir, akan tetapi pengendalian Intern dilaksanakan oleh personil di setiap jejang organisasi yang mencakup dewan komisaris, manajemen, dan personil lainnya.

c) Diharapkan mampu memberikan keyakinan yang memadai bagi dewan dewan komisaris dan manajemen entitas. Keyakinan tersebut bukanlah keyakinan mutlak karena pengendalian Intern memiliki keterbatasan-keterbatasan. 
d) Ditujukan untuk mencapai tujuan yang saling berkaitan, yakni pelaporan keuangan, kepatuhan dan operasi.

Konsep-konsep dasar pengendalian intern tersebut merupakan suatu konsep yang dapat diterapkan sebagai acuan bukan hanya untuk entitas besar, namun juga entitas kecil dan menengah dalam rangka mencapai tujuan entitas. Konsep tersebut perlu ditaati oleh seluruh jenjang personil sehingga tujuan entitas dapat diraih secara efektif.

\subsection{Tujuan Pengendalian Intern}

Pengendalian Intern yang dirancang oleh suatu entitas memiliki tujuan tertentu. Tentunya dalam proses pencapaian tersebut, entitas perlu mempertimbangkan konsep biaya dan manfaat. Beberapa tujuan pengendalian Intern diungkapkan sebagai berikut:

Arens (2006) mengemukakan bahwa tujuan pengendalian Intern adalah:

a) Reliability of financial reporting (keandalan dalam laporan keuangan)

Laporan keuangan merupakan media yang digunakan oleh manajemen dalam mengkomunikasikan kondisi perusahaannya dan sebagai sarana pertanggungjawaban hukum dan profesionalitas manajemen kepada investor, kreditor dan para pengguna laporan keuangan lainnya.

b) Aktivitas operasional perusahaan yang efektif dan efisien

Pengendalian Intern dimaksudkan agar kegiatan operasional entitas dapat berjalan secara efisien dalam penggunaan sumber daya entitas namun tujuan entitas dapat dicapai secara efektif.

c) Kepatuhan terhadap peraturan dan hukum

Salah satu tujuan pengendalian Intern adalah agar entitas dapat mentaati peraturan dan hukum, karena tidak sedikit aturan dan hukum melekat pada entitas dalam menjalankan operasinya seperti aturan perpajakan yang belakangan ini pihak pemerintah menaruh perhatian lebih kepada entitas kecil dan menengah dalam peraturan perpajakannya.

Dilaksanakannya pengendalian Intern tidak menjamin suatu entitas sepenuhnya dapat mencapai tujuan-tujuan pengendalian Intern di atas. Namun setidaknya, pengendalian Intern dapat meminimalisir resiko terhadap penyalahgunaan dan kesalahan dalam operasional entitas.

\subsection{Kriteria Pengendalian Intern yang Baik}

Dibutuhkan kriteria yang jelas mengenai pengendalian intern yang baik agar para pelaku UMKM memiliki patokan dalam kegiatan operasi pengendaliannya. Suatu pengendalian intern yang baik di dalam perusahaan biasanya memiliki struktur organisasi dan sistem otorisasi yang jelas, memiliki sistem akuntansi beserta staf auditor internnya, kebijakan personalia yang baik dan dewan komisaris yang berada di dalamnya bersifat aktif dan kompeten (Bailey : 1979) Sedangkan menurut Tunggal (1995) pengendalian intern yang baik mencakup ciri-ciri sebagai berikut:

a) Struktur organisasi memiliki pemisahan tanggung jawab fungsional yang sesuai

b) Sistem prosedur otorisasi dan pencatatan telah sesuai agar memungkinkan pengendalian yang wajar atas harta, hutang, pendapatan dan biaya

c) Cara kerja yang wajar harus digunakan dalam pelaksanaan tugas dan fungsi masing-masing bagian organisatoris. 
d) Kepegawaian dengan mutu yang sepadan dengan tanggung jawabnya.

Pengendalian intern yang baik merupakan keniscayaan bagi pencapaian tujuan organisasi/perusahaan baik perusahaan dengan skala besar maupun perusahaan kecil. Ciri-ciri pengendalian intern yang baik tersebut dapat dijadikan acuan untuk pelabelan suatu organisasi apakah telah menerapkan penegendalian internya dengan baik atau sebaliknya.

\subsection{Komponen Pengendalian Intern}

Setiap sistem tentunya memiliki komponen atau unsur yang saling berkaitan dan bekerja sama. Komponen pengendalian intern merupakan suatu bagian yang harus dipenuhi dalam rangka menghasilkan pengendalian yang memadai. Komponen pengendalian intern tersebut diartikan oleh Arens (2006) sebagai berikut:

"Internal control include five categories of control that management's control objectives will be met. There are called the components of internal control and are: (1) the control environment, (2) risk assessment, (3) control activities, (4) information and communication, (5) monitoring".

Komponen-komponen pengendalian tersebut dijelaskan sebagai berikut:

1) Lingkungan Pengendalian

Lingkungan pengendalian merupakan dasar dari semua unsur pengendalian intern, yang membentuk disiplin dan struktur. Berbagai faktor yang membentuk lingkungan pengendalian dalam suatu entitas antara lain: nilai integritas dan etika, komitmen terhadap kompetensi, dewan komisaris dan komite audit, filosofi dan gaya operasi, struktur organisasi, pembagian wewenang dan tanggung jawab, kebijakan dan praktik sumber daya manusia serta kesadaran pengendalian.

2) Aktivitas Pengendalian

Komponen ini terdiri dari prosedur dan kebijakan yang berutujuan untuk memastikan bahwa karyawan telah melaksanakan semua petunjuk yang diberikan oleh manajemen.

3) Penaksiran Risiko

Penaksiran risiko adalah identifikasi, analisis, dan pengelolaan risiko entitas yang berkaitan aktivitas untuk mencapai tujuan entitas sesuai dengan aturan yang berlaku. Penaksiran risiko manajemen harus mencakup pertimbangan tertentu terhadap risiko yang timbul dari perubahan keadaan seperti bidang baru bisnis, perubahan standar, hukum dan peraturan baru, teknologi baru dan pertumbuhan pesat entitas yang menuntut perubahan fungsi pengelolaan entitas.

4) Informasi dan Komunikasi

Informasi dapat tersampaikan dengan cara komunikasi yang merupakan penyampaian data-data tertentu seperti penyimpangan ataupun hal lainnya kepada pihak dalam struktur organisasi yang lebih tinggi dalam suatu perusahaan. Informasi yang dimaksud merupakan data aktivitas personil dalam perusahaan yang berhubungan dengan pihak lain.

5) Pemantauan

Dapat dikatakan bahwa pemantauan merupakan evaluasi hasil penerapan pengendalian intern sehingga pada akhir proses pemantauan dapat ditarik kesimpulan 
apakah pengendalian intern diterapkan dengan baik. Hal yang menjadi perhatian adalah, pemantauan harus dilaksanakan oleh orang yang kompeten di bidangnya agar hasil pemantauan dapat dipertanggungjawabkan.

\subsection{Efektivitas Penerapan Pengendalian Intern}

Pengendalian intern yang efektif diartikan sebagai tujuan pengendalian intern di perusahaan dapat dicapai. Hal ini dapat diketahui dari keamanan harta perusahaan yang terjaga, data-data akuntansi yang dapat diandalkan, seluruh aktivitas perusahaan berjalan secara efisien dan peraturan-peraturan di dalam perusahaan ditaati oleh pelaku organisasi.

\subsection{Definisi Usaha Mikro, Kecil dan Menengah (UMKM)}

UMKM (Usaha Mikro, Kecil dan Menengah) didefinisikan oleh beberapa sumber beserta kriterianya sebagai berikut:

a. Badan Pusat Statistik (BPS), memandang UMKM dari jumlah tenaga kerja. Usaha kecil memiliki tenaga kerja dengan jumlah 6 - 19 orang. Usaha menengah memiliki jumlah tenaga kerja 20 - 99 orang.

b. Mentri hukum dan hak asasi manusia Republik Indonesia menekankan pada segi aset dan omzet. Usaha mikro memiliki aset bersih paling banyak Rp. 50.000.000,tidak termasuk tanah dan bangunan, penjualan tahunan paling banyak $\mathrm{Rp}$. 300.000.000,-. Usaha kecil memiliki aset lebih dari Rp. 50.000.000,- diluar tanah dan bangunan, atau omzet tahunan lebih dari Rp. 300.000.000,- sampai Rp. 2.500.000.000,-. Usaha menengah memiliki aset lebih dari Rp. 500.000.000,sampai Rp. 10.000.000.000, atau omzet tahunan lebih dari Rp. 2.500.000.000,sampai Rp. 50.000.000.000,-.

c. Bank Dunia mengartikan usaha kecil dan menengah adalah usaha yang pekerjaannya di bawah 150 orang dan memiliki aset kurang dari US\$500.000 diluar tanah dan bangunan.

Usaha mikro, kecil dan menengah merupakan pemberi kontribusi yang sangat besar bagi perekonomian Indonesia khususnya pada masa Masyarakat Ekonomi Asean (MEA) ini sehingga diperlukan perhatian dan indentifikasi khusus mengenai unsurunsur pengembangannya.

\subsection{Pengendalian Intern di UMKM}

Shanmugam, et.al (2012) mengemukakan bahwa usaha kecil dan menengah lebih rentan terhadap kecurangan oleh karyawan dan memiliki kemungkinan kerugian yang lebih besar dibandingkan dengan perusahaan besar. Penerapan pengendalian intern di suatu entitas akan bergantung salah satunya pada ukuran perusahaan. Pada kenyataannya akan lebih sulit melakukan pemisahan tugas yang memadai pada perusahaan kecil dikarenakan keterbatasan jumlah karyawan yang dimiliki (Tunggal: 1995). Selain itu Grollman dan Colby (1978) mengemukanan masalah yang biasa dihadapi oleh perusahaan berskala kecil dalam penerapan internya adalah prosedur yang tidak dirancang secara formal, kurangnya pengalaman manajeman di bidang keuangan, tidak adanya pemisahan fungsi pekerjaan, akses terhadapa harta kekayaan perusahaan terbuka untuk karyawan serta sistem pelaporan, perencanaan, analisis dan pengawasan masih informal. 
Berdasarkan definisi di atas, dapat ditarik kesimpulan bahwa perancangan sistem pengendalian intern untuk perusahaan kecil akan sulit apabila mengacu pada sistem pengendalian intern pada perusahaan besar. Pengendalian intern yang diterapkan harus mempertimbangkan cost and benefit yang akan muncul, dalam artian manfaat yang diperoleh dari penerapan konsep pengendalian intern tersebut dinilai lebih besar daripada biaya yang dikeluarkannya.

Snyder (1989) pada Journal of Small Business Management dalam penelitiannya yang berjudul Using Internal Control to Reduce Employee theft in small Business mengemukakan bahwa penerapan konsep pengendalian intern pada perusahaan kecil bertujuan untuk mengamankan harta kekayaan perusahaan dari tindak kecurangan yang mungkin dilakukan oleh karyawannya. Snyder pun berpendapat bahwa pandangan antara pemilik dan karyawan mengenai konsep pengendalian intern harus sejalan.

Hasil penelitian yang dilakukan oleh Snyder (1989) menyebutkan bahwa perusahaan kecil memiliki sebagian besar sub komponen pengendalian intern yang menyangkut kas dan sebagian yang lain mengenai persediaan, penggajian,utang, piutang, usaha umum serta investasi dengan total keseluruhan sub komponen tersebut berjumlah 41. Selain penelitian Snyder (1989), penelitian Stelzer (1964) pun memfokuskan pada hal yang sama. Penelitian tersebut menghasilkan kuisioner pengendalian internal (Internal Control Questionnaire) bagi perusahaan kecil yang mengupas masalah pengendalian intern pada ranah umum, akuntansi, penjualan, penagihan, penerimaan kas, pengeluaran kas, persediaan dan pembelian barang dagang, penggajian serta aktiva tetap sehinga dapat menjadi model acuan bagi perusahaan kecil untuk maksimalisasi pengelolaan perusahaannya.

\section{METODE PENELITIAN}

Penelitian ini menggunakan kuisioner sebagai alat pengumpul data primer. Selain itu, penelitian ini menggunakan metode pengambilan sampel nonprobability sampling dimana memberi peluang yang sama bagi setiap anggota untuk menjadi sampel penelitian (Sugiyono, 2013). Pada penelitian ini digunakan sampel yakni UMKM yang tergabung dalam Wirausaha Muda Jawa Barat 2014.

Penelitian ini mengukur variabel pengendalian intern pada UMKM dengan instrumen Internal Control Quisitionnaire (Snyder et. Al: 1989, Stelzer: 1964). Dimensi dari instumen tersebut terdiri atas pertanyaan-pertanyaan sebagai berikut:

a. Cash, meliputi pelarangan penggunaan cek yang tidak memiliki nomor cetak, secara periodik dilakukan pemeriksaan petty cash, dan sebagainya.

b. Pembayaran gaji, contohnya pertanyaan mengenai penggunaan cek untuk pembayaran gaji dan upah.

c. Investasi, seperti penggunaan safe deposit box untuk menyimpan surat-surat berharga.

d. inventory, misalnya menghitung persediaan fisik secara berkala.

e. Umum, misalnya pemisahan fungsi (akuntansi) di perusahaan. 
f. Piutang dagang dan piutang wesel, terdiri dari pertanyaan-pertanyaan pengendalian terkait piutang seperti pengiriman tagihan bulanan kepada pelanggan secara rutin.

g. Hutang dagang, terdiri dari pertanyaan terkait pengendalian hutang dagang seperti adanya pengecekkan ulang order pembelian setelah proses pembayaran.

h. Penjualan, meliputi pertanyaan seperti adanya pencatatan terhadap penjualan.

i. Aktiva tetap, terdiri dari pertanyaan yang mencakup pengamanan aktiva tetap seperti membuat nomor untuk mengidentifikasi aktiva tetap.

Hipotesis dalam penelitian ini adalah:

$\mathrm{H}_{0}$ : Penerapan pengendalian intern pada UMKM belum efektif dilaksanakan

$\mathrm{H}_{2}$ : Penerapan pengendalian intern yang diterapkan pada UMKM sudah efektif dilaksanakan

\section{HASIL DAN PEMBAHASAN}

\subsection{Gambaran Umum Responden}

Responden yang digunakan dalam penelitian ini adalah penggiat UMKM di Kota Bandung yang terdaftar dalam UMKM Wirausaha Muda Jabar 2014. Berikut karakteristik data kuisioner berdasarkan jenis usaha:

Tabel 1. Karakteristik Data Kuisioner Berdasarkan Jenis Usaha

\begin{tabular}{|l|c|c|}
\hline Kriteria & Jumlah & Persentase (\%) \\
\hline Jasa & 18 & 24.00 \\
\hline Manufaktur & 31 & 41.33 \\
\hline Dagang & 26 & 34.67 \\
\hline Jumlah & 75 & 100.00 \\
\hline
\end{tabular}

Berdasarkan tabel 1 dapat diketahui bahwa responden sebagian besar bergerak dalam usaha manufaktur (41.33\%) yaitu usaha konveksi, kerajinan tangan, industri makanan rumahan dan sebagainya. Selanjutnya $24 \%$ merupakan perusahan jasa seperti laundry, biro travel dan sebagainya. Kemudian $44.67 \%$ bergerak di bidang usaha dagang baik itu makanan, alat-alat kebersihan, fashion dan sebagainya.

Selanjutnya karakteristik kuisioner berdasarkan jumlah karyawan disajikan dalam tabel berikut:

Tabel 2. Karakteristik Data Kuisioner Berdasarkan Jumlah Karyawan

\begin{tabular}{|l|c|c|}
\hline \multicolumn{1}{|c|}{ Kriteria } & Jumlah & Persentase (\%) \\
\hline$<6$ orang & 36 & 48.00 \\
\hline 6 s/d 19 orang & 30 & 40.00 \\
\hline 20 s/d 99 orang & 7 & 9.33 \\
\hline$>99$ orang & 2 & 2.67 \\
\hline Jumlah & 75 & 100.00 \\
\hline
\end{tabular}

Berdasarkan tabel 2 sebanyak 48\% responden memiliki karyawan sejumlah kurang dari enam orang, $40 \%$ responden memiliki karyawan antara enam hingga Sembilan 
belas orang, 9.33\% memiliki karyawan diantara dua puluh hingga 99 orang karyawan dan $2.67 \%$ responden memiliki karyawan melebihi 99 orang.

Karakteristik data kuisioner berdasarkan jumlah aset disajikan dalam tabel berikut:

Tabel 3. Karakteristik Data Kuisioner Berdasarkan Jumlah Aset

\begin{tabular}{|l|c|c|}
\hline Kriteria & Jumlah & Persentase (\%) \\
\hline < Rp. 200.000.000,- & 30 & 40.00 \\
\hline Rp. 200.000.000,-s/d Rp. 500.000.000,- & 20 & 26.67 \\
\hline Rp. 500.000.000,-s/d Rp. 600.000.000,- & 20 & 26.67 \\
\hline >Rp.600.000.000,- & 5 & 6.67 \\
\hline Jumlah & 75 & 100.00 \\
\hline
\end{tabular}

Berdasarkan tabel 3 dapat diketahui bahwa sebagian besar (40\%) responden terdiri dari penggiat UMKM dengan aset kurang dari dua ratus juta rupiah (Rp 200.000,00). Sebesar 26,67\% memiliki aset bersisar antara Rp. 200.000.000,- sampai dengan Rp. 500.000.000,-, 26,67\% memiliki aset berkisar antara Rp. 500.000.000,sampai dengan Rp. 600.000.000,- dan sisanya 6,67\% terdiri atas penggiat UMKM dengan aset lebih dari enam ratus juta rupiah (Rp. 600.000.000,-). Aset yang dimaksud adala aset tidak termasuk tanah dan bangunan.

\subsection{Pengujian Validitas dan Reliabilitas}

Pengujian validitas dilakukan melalui nilai koefisien korelasi skor butir pertanyaan dengan skor totalnya. Kriteria yang digunakan yaitu jika koefisien korelasi setiap butir pertanyaan melebihi atau sama dengan nilai Tabel $\mathrm{R}$ (Korelasi $\geq$ nilai tabel), maka pertanyaan tersebut dinyatakan valid. Perhitungan $r_{\text {tabel }}=0,227$ (nilai dilihat dari RTable dengan $\mathrm{N}=5$ atau $\mathrm{df}=73$ ). Sedangkan nilai $\mathrm{r}$ hitung berada di rrentang 0,412 dan 0,748 sehingga pengujian validitas menunjukan bahwa seluruh point pertanyaan terbilang valid. Hal ini berarti bahwa pengujian dapat dilanjutkan ke tahap berikutnya.

Uji reliabilitas dalam penelitian ini menggunakan software SPSS 25.0 dengan koefisien Cronbach Alpha. Instrumen penelitian dianggap reliabel apabila nilai Cronbach Alpha $>0,6$. Hasil pengujian reliabilitas yang disajikan dalam satu tabel sebagai berikut:

\begin{tabular}{cc}
$\begin{array}{c}\text { Tabel 4. Hasil Uji Reliabilitas } \\
\text { Cronbach's } \\
\text { Alpha }\end{array}$ & N of Items \\
\hline .941 & 32 \\
\hline
\end{tabular}

Berdasarkan tabel 4 diketahui bahwa data kuisioner mengenai efektivitas pengendalian internal reliabel sehingga data dapat dilanjutkan ke pengujian berikutnya.

\subsection{Deskripsi Data}

Jawaban responden atas pernyataan di kuisioner akan diberi skor antara satu sampai lima dan selanjutnya akan digunakan dalam perhitungan skor terendah dan tertinggi yang berguna dalam klasifikasi data. Skor terendah diperoleh dari perkalian antara skor terendah (yaitu $=1$ ) dengan total responden (75) kemudian dikalikan banyaknya item pernyataan kuesioner. Skor tertinggi didapat dari perkalian antara skor 
tertinggi (yaitu $=5$ ) dengan total responden (75) kemudian dikalikan banyaknya item pernyataan kuesioner. Rentang skor diperoleh dengan perhitungan:

$$
\text { Rentang Skor }=\frac{\text { Skor Tertinggi }- \text { Skor Terendah }}{\text { Jumlah Kategori }}
$$

Setelah diberi skor, jawaban atas kuisioner yang telah diisi oleh responden kemudian dimasukan ke dalam kriteria. Skor terkecil yaitu 1 dikalikan dengan 75 responden dan dikalikan dengan total item pertanyaan (32) yaitu 2400. Skor terbesar yaitu 5 dikalikan dengan 75 responden dan dikalikan dengan total item pertanyaan (32) yaitu 12000. Range skor awal dan akhir untuk masing-masing kriteria merupakan selisih dari skor awal kriteria tertinggi (12000) dikurangi dengan skor awal dari kriteria paling rendah (2400) dibagi dengan jumlah kriteria (5).

Tabel 5. Deskripsi Data

\begin{tabular}{|l|c|c|}
\hline \multicolumn{1}{|c|}{ Kriteria } & $\begin{array}{c}\text { Skor } \\
\text { Awal }\end{array}$ & Skor Akhir \\
\hline Tidak Baik & 2400 & 4319 \\
\hline Kurang Baik & 4320 & 6239 \\
\hline Cukup Baik & 6240 & 8159 \\
\hline Baik & 8160 & 10079 \\
\hline Sangat Baik & 10080 & 12000 \\
\hline Skor Total Kuisioner & 8049 & Cukup Baik \\
\hline
\end{tabular}

Berdasarkan tabel 5 diketahui bahwa total skor kuisioner yaitu 8049 berada dalam kriteria cukup baik. Artinya pengendalian intern yang diterapkan oleh para penggiat UMKM di Kota Bandung secara umum dinilai cukup baik.

Pengujian SPSS dilakukan untuk memastikan kebenaran data sebelumnya dan hasilnya dapat dilihat dari tabel berikut:

Tabel 6. Statistik Deskriptif

\begin{tabular}{|l|c|c|c|c|c|c|}
\hline \multicolumn{7}{|c|}{ Descriptive Statistics } \\
\hline & $\mathrm{N}$ & Minimum & \\
\hline Total Kuisionumer & 75 & 71 & 149 & 107.32 & 22.281 & 496.437 \\
\hline Valid N (listwise) & 75 & & & & & \\
\hline
\end{tabular}

Berdasarkan tabel 6, dapat dilihat bahwa skor rata-rata 107,32. Apabila dikalihan dengan jumlah total kuisioner (75) maka akan menghasilkan angka 8049. Angka tersebut berada dalam range kriteria cukup baik. Berdasarkan hasil wawancara dan observasi dapat diketahui bahwa penyebab dari kurang maksimalnya penerapan pengendalian intern disebabkan sebagian besar karena faktor sumber daya manusia. Struktur organisasi yang sangat sederhana dan rangkap deskripsi pekerjaan membuat kegiatan pengendalian intern di UMKM ini cenderung sulit sehingga penggiat UMKM merasa biaya lebih tinggi daripada manfaatnya apabila menambah kuantitas sumber daya manusia. Faktor pendidikan, pengetahuan, dan rendahnya tingkat kesadaran tentang pentingnya pengendalian intern serta akuntansi dapat menjadi beberapa faktor yang menyebabkan fenomena ini (Kurniawati, Nugroho, dan Setiawati, 2011).

Kriteria yang didapat dari hasil penelitian ini merupakan bukan kriteria yang paling baik sehingga diharapkan dapat direkomendasikan usulan yang dapat 
memaksimalkan penerapan pengendalian intern para penggiat UMKM di Kota Bandung. Hal ini diperlukan agar kegiatan operasional perusahaan dapat berjalan secara efisien dalam penggunaan sumber daya namun tujuan perusahaan dapat dicapai secara efektif.

\subsection{Deskripsi Statistik Per Indikator}

Setiap indikator perlu dideskripsikan dengan jelas agar terlihat jelas detail data kuisioner yang diolah. Tabel berikut ini memberikan deskripsi nilai bagi masingmasing indikator:

Tabel 7. Deskripsi Statistik Per Indikator

\begin{tabular}{|l|l|l|l|l|l|}
\hline & $\mathrm{N}$ & Min & Max & Mean & Std. Dev \\
\hline Cash & & 10 & 39 & 26.00 & 6.621 \\
Penggajian & & 4 & 20 & 12.91 & 4.064 \\
Investasi & & 5 & 3.60 & 1.263 \\
Inventory & & 5 & 15 & 10.33 & 2.673 \\
Umum & 75 & 5 & 3.31 & 1.065 \\
Piutang & 4 & 20 & 13.64 & 3.408 \\
Hutang Dagang & 8 & 25 & 16.68 & 3.891 \\
Penjualan & 6 & 15 & 10.61 & 2.404 \\
Aktiva Tetap & 3 & 15 & 10.24 & 2.735 \\
Valid N (listwise) & & & & \\
\hline
\end{tabular}

Selain itu, disajikan tabel perbandingan pemusatan data dengan nilai idealnya. Berikut penjabarannya:

Tabel 8. Tabel Perbandingan Pemusatan Data

\begin{tabular}{|l|c|c|c|c|c|}
\hline \multicolumn{1}{|c|}{ Deskripsi } & $\begin{array}{c}\text { Jum } \\
\text { Var }\end{array}$ & Maks & $\begin{array}{c}70 \% \mathbf{x} \\
\text { maks }\end{array}$ & Mean & Selisih \\
\hline Kas & 8 & 40 & 28.00 & 26.00 & 2.00 \\
\hline Penggajian & 4 & 20 & 14.00 & 12.91 & 1.09 \\
\hline Investasi & 1 & 5 & 3.50 & 3.60 & -0.10 \\
\hline Persediaan & 3 & 15 & 10.50 & 10.33 & 0.17 \\
\hline Umum & 1 & 5 & 3.50 & 3.31 & 0.19 \\
\hline Piutang & 4 & 20 & 14.00 & 13.64 & 0.36 \\
\hline Hutang Dagang & 5 & 25 & 17.50 & 16.68 & 0.82 \\
\hline Penjualan & 3 & 15 & 10.50 & 10.61 & -0.11 \\
\hline Aktiva Tetap & 3 & 15 & 10.50 & 10.24 & 0.26 \\
\hline Jumlah & 32 & 160 & 112.00 & 107.32 & 4.68 \\
\hline
\end{tabular}

Berdasarkan tabel 8 diketahui bahwa indikator investasi memiliki rata-rata hitung diatas nilai maksimalnya sehingga menghasilkan selisih hitung nilai minus. Hal ini berarti bahwa setiap indikator dari pengendalian internal UMKM di Kota Bandung sudah terbilang baik, namun ada indikator yang masih dinilai kurang baik yaitu indikator investasi dan penjualan.

Keterangan yang didapat oleh penulis, para penggiat UMKM di Kota Bandung memang sangat sedikit yang menggunakan safe deposit box atau sejenisnya sebagai media 
penyimpanan surat-surat berharga. Mereka menilai bahwa penggunaan media tersebut kurang efisien. Hal ini dapat terjadi mengingat data responden sebagian besar memiliki aset kurang dari Rp 200.000.000,-s sehingga indikator investasi bukan menjadi sorotan utama. Safe deposit box tetap menjadi solusi dalam penyimpanan surat berharga walaupun secara hitungan jangka pendek kurang efisien, namun akan menguntungkan dalam jangka panjang.

Indikator penjualan pun menunjukan selisih minus yang berarti penerapan efektivitas untuk indikator ini dikatakan belum cukup baik. Hal ini berarti bahwa pencatatan terhadap transaksi penjualan tidak selalu lengkap, Dokumen tidak selalu memiliki nomor urut tercetak terkait dengan penjualan, pengiriman barang dan penerimaan kas, dokumentasi yang kurang lengkap atas bukti bukti penjualan.

Penjualan merupakan unsur yang sangat penting atas keberlangsungan usaha perusahaan, namun untuk usaha yang relatif kecil, dokumentasi dan pengenalian intern yang bersifat administratif sering diabaikan. Penyebabnya adalah kurangnya sumber daya manusia yang dapat memfokuskan diri pada hal-hal administratif. Penambahan jumlah sumber daya manusia sering kali bukan menjadi solusi karena perbandingkan biaya dan manfaat yang tidak menguntungkan. Penyusunan standar operasi prosedur dalam administrasi bidang penjualan serta kedisiplinan untuk selalu patuh pada SOP dapat dijadikan solusi dalam permasalahan ini. Sanksi yang tegas pun dapat ditegakkan untuk permasalahan yang lebih kompleks di bidang administrasi penjualan. Jaya Khumar (2012) menyatakan bahwa manajemen harus memelihara kendali yang dapat memberikan jaminan memadai atas aset dan catatan entitas. Sehingga dapat dikatakan, permasalahan tersebut dapat dikendalikan dengan pengawasan manajemen yang memadai.

\subsection{Pengujian Normalitas Data}

Berikut disajikan tabel hasil pengujian normalitas data untuk variabel efektivitas pengendalian intern pada UMKM:

\section{Tabel 9. Output Hasil Pengujian Normalitas Data}

One-Sample Kolmogorov-Smirnov Test

\begin{tabular}{lll}
\hline $\mathrm{N}$ & & Total Kuisioner \\
\hline Normal Parameters $^{\mathrm{a}, \mathrm{b}}$ & Mean & 75 \\
\cline { 2 - 3 } & Std. Deviation & 22.281 \\
\hline Most Extreme Differences & Absolute & .102 \\
\cline { 2 - 3 } & Positive & .088 \\
\cline { 2 - 3 } & Negative &. .102 \\
\hline Test Statistic & & .102 \\
\hline Asymp. Sig. (2-tailed) & & $.051^{\mathrm{c}}$ \\
\hline
\end{tabular}

Data dikatakan berdistribusi normal apabila nilai signifikansi lebih besar daripada 0,05 sehingga dapat dikatakan bahwa data dalam penelitian ini berdistribusi normal karena memiliki signifikansi 0,051. Pengujian normalitas data ini dilakukan agar dapat dilakukan pengujian data dengan menggunakan uji t. 


\subsection{Pengujian Hipotesis}

Hipotesis yang telah diuraikan sebelumnya akan diujikan dengan uji t untuk mengetahui apakan penerapan pengendalian intern pada UMKM di Kota Bandung telah dilaksanakan secara efektif atau belum. Berikut hipotesis dari penelitian ini:

$\mathrm{H}_{0}$ : Penerapan pengendalian intern pada UMKM di Kota Bandung belum efektif $(t \leq$ $70 \%)$

$\mathrm{H}_{\mathrm{a}}$ : Penerapan pengendalian intern pada UMKM di Kota Bandung sudah efektif $(t>$ $70 \%)$

Berikut disajikan deskripsi data dan hasil output uji t:

Tabel 10. Statistik Deskriptif untuk Uji t One-Sample Statistics

\begin{tabular}{|l|c|c|c|c|}
\hline & $\mathrm{N}$ & Mean & Std. Deviation & Std. Error Mean \\
\hline Total Kuisioner & 75 & 107.32 & 22.281 & 2.573 \\
\hline
\end{tabular}

Tabel 11. Output Hasil Uji t One-Sample Test

\begin{tabular}{|c|c|c|c|c|c|c|}
\hline & \multicolumn{6}{|c|}{ Test Value $=112$} \\
\hline & \multirow[b]{2}{*}{$\mathrm{t}$} & \multirow[b]{2}{*}{$\mathrm{df}$} & \multirow[b]{2}{*}{ Sig. (2-tailed) } & \multirow{2}{*}{$\begin{array}{c}\text { Mean } \\
\text { Difference }\end{array}$} & \multicolumn{2}{|c|}{$\begin{array}{l}\text { 95\% Confidence Interval of the } \\
\text { Difference }\end{array}$} \\
\hline & & & & & Lower & Upper \\
\hline Total Kuisioner & -1.819 & 74 & .073 & -4.680 & -9.81 & .45 \\
\hline
\end{tabular}

Berdasarkan tabel 12 diketahui bahwa nilai Sig. (2-tailed) =0,073. Karena nilai Sig. $>0,05$, maka hasil pengujian terbilang tidak signifikan. sehingga $\mathrm{H}_{0}$ diterima, artinya pengendalian intern pada UMKM di Kota Bandung belum efektif diterapkan sehinga tidak ada perubahan yang signifikan. Selain itu hasil perhitungan nilai t adalah sebagai berikut:

$$
t_{\text {tabel }}=1,993 t_{\text {hitung }}=-1,819
$$

Karena nilai $t_{\text {hitung }}=-1,819<t_{\text {tabel }}=1,993$ maka $H_{0}$ diterima artinya pengendalian intern pada UMKM di Kota Bandung belum efektif diterapkan sehinga tidak ada perubahan yang signifikan. Hasil pengujian ini apabila dihubungkan dengan statistik deskriptif sebelumnya yang menyatakan bahwa penerapan pengendalian intern yang dilakukan oleh para penggiat UMKM di Kota Bandung masih terbilang cukup baik sangatlah logis mengingat nilai dari kriteria cukup baik itu berada di antara baik dan tidak baik.

Diperlukan usulan rekomendasi strategi agar penerapan UMKM di Kota Bandung dapat lebih efektif sehingga diharapkan akan menunjang kelangsungan usaha jangka panjang, lebih jauh lagi akan menopang perekonomian negara baik dari sisi peningkatan pendapatan per kapita dan produk domestik bruto maupun pemasukan negara dari penerimaan pajaknya. 


\section{PENUTUP}

Berdasarkan pengumpulan data, pengujian serta pemaparan sebelumnya, dapat ditarik kesimpulan bahwa pengendalian intern yang diterapkan UMKM di Kota Bandung masih terbilang cukup baik dan belum efektif. Penyebabnya adalah struktur organisasi yang sangat sederhana dan rangkap deskripsi pekerjaan, juga analisis biaya dan manfaat yang cenderung kurang mendukung pelaksanaan pengendalian intern secara penuh. Selain itu, terdapat beberapa subkomponen pengendalian intern yang belum maksimal diterapkan oleh UMKM di Kota Bandung, yakni investasi dan penjualan. Hal ini disebabkan para pelaku UMKM cenderung memandang penggunaan safe deposit box masih dinilai tidak efisien serta tidak adanya fungsi atau bagian dalam perusahaan yang memfokuskan pada hal terkait administratif.

Mengacu pada kesimpulan di atas, penulis membuat suatu rekomendasi agar para penggiat UMKM diberikan sosialisasi dan workshop berkesinambungan khusus mengenai topik pengendalian intern. Program ini dapat dilakukan dengan basis kerja sama antara Pembina UMKM wilayah tertentu dengan pihak akademisi atau institusi pendidikan tinggi dalam program pengabdian kepada masyarakat. Selain itu, pemantauan yang berkelanjutan dari Pembina UMKM pun diperlukan agar penggiat UMKM dapat menerapkan pengendalian intern secara konsisten.

\section{DAFTAR PUSTAKA}

Arens, Alvin A; Randal J Elder, and Mark S Beasley. 2006. Auditng and Assurance Service; an Integrated Approach, Eleventh Edition. New Jersey: Prentice Hall.

Arens, Alvin A; Randal J Elder, and Mark S Beasley. 2015. Auditng dan Jasa Assurance; Pendekatan Terintegrasi Jilid 1 Edisi Lima Belas- Jakarta. Erlangga.

Arens, Alvin A., and james K. Loebbecke. 2006. Auditing : An Integrated Approach. $8^{\text {th }}$ edition. Englewood. New Jersey: Prentice Hall Inc

Bailey, Larry P. 1985. Contemporary Auditing.

Grollman, W.K and Colby, R.W. 1978. Internal Control for Small Businessess. The Journal of Accountancy, pp64-67.

Harahap, Sofyan Syafri. 1995. Auditing Perusahaan Kecil. Jakarta: Bumi Aksara.

Jof, t. 1978. A Small Business Internal Control Questionarie. Study Group on Audit Techniques, Canadian Institute of Charter-ed Accountants, July 1978, pp 53-54.

Kurniawati, Heny. 2011. Sistem Pengendalian Intern Pada Perusahaan Kecil dan Menengah. Binus Business Review Vol 2 No. 2 : 923-935.

Kurniawati, E. T., Nugroho, and Umiyarsih 2011. Understanding IT adoption decisions in small business. Information and Management, pp. 269-285.

Mulyadi. 2016. Sistem Akuntansi. Edisi Keempat. Jakarta: Salemba Empat.

Mulyadi. 2013. Auditing. Edisi Keenam. Buku 1. Jakarta: Salemba Empat.

Montgomery, J. 2003. Internal Control a must, even for small businesses. July 11-17 2003 Fort Worth Business Press.

Menteri Hukum dan Hak Asasi Manusia. 2008. Undang-Undang Republik Indonesia Nomor 20 Tahun 2008 Tentang Usaha Mikro, Kecil dan Menengah. Jakarta. 
Shanmugam, Jaya Khumar, et.al. 2012. An Explanatory Study of Internal Control and Fraud Prevention Measures in SMEs. International Journal of Business Research and Management (IJBRM) Vol 3 Issue 2.

Snyder, NH, Broome, OW, Zimmerman, K. 1989. Using Internal Control to Reduce Employee Theft in Small Businessess. Journal of Small Business Management.

Stelzer, Herbet. 1964. Evaluation of Internal Control in Small Audits. The Journal of Accountancy, November 1964, pp 55-61.

Sugiyono. 2013. Metode Penelitian Bisnis. Bandung: Alfabeta.

Tunggal, Amin Wijaya. 1995. Struktur Pengendalian Intern. Jakarta : PT. Rineka Cipta.

Internet:

Alwan Ridha. 2016. Bandung targetkan 8.376 wirausaha anyar di 2016. Dapat diakses di: http://bandungkita.net/2016/05/bandung-targetkan-8-376-wirausaha-anyardi-2016/

Diana Audrien. 2016. Kontribusi UMKM terhadap PDB Tembus Lebih dari 60 Persen. Dapat diakses di: http://www.cnnindonesia.com/ekonomi/20161121122525-92174080/kontribusi-umkm-terhadap-pdb-tembus-lebih-dari-60-persen/

Ikatan Akuntan Indonesia. 2016. IAI Siapkan Pilar Baru SAK untuk UMKM. Dapat di akses: http://iaiglobal.or.id/v03/berita-kegiatan/detailberita-915=iai-siapkanpilar-baru-sak-untuk-umkm

Kementerian Keuangan Indonesia. 2015. Peran Penting UKM dorong Perekonomian Indonesia. Dapat diakses di: https://www.kemenkeu.go.id/Berita/peranpenting-ukm-dorong-perekonomian-indonesia

Pramdia Arhando. 2016. Kota Bandung Menjadi Contoh Pengembangan UMKM. Dapat diakses: http://bisniskeuangan.kompas.com/read/2016/10/06/220327326/kota.band ung.menjadi.contoh.pengembangan.umkm

Siprianus Edi Hardum. (2015). Kontribusi Besar Sektor UKM untuk Ekonomi Nasional. http://www.beritasatu.com/ekonomi/225157-kontribusi-besar-sektorukm-untuk-ekonomi-nasional.html

Suci Rahmadhani. 2016. UMKM Bandung Siap Go Internasional Dengan Dukungan Facebook. http://goukm.id/umkm-bandung-siap-go-internasional-dengandukungan-facebook/

2014. Kadin: Empat Kendala Penghambat Perkembangan UMKM. Dapat diakses di: http://www.kabarbisnis.com/read/2845011 